\title{
Leaf Spot Diseases on Winter Wheat Influenced by Nitrogen, Tillage, and Haying after a Grass-Alfalfa Mixture in the Conservation Reserve Program
}

\author{
J. M. Krupinsky, Plant Pathologist, and D. L. Tanaka, Soil Scientist, USDA, Agriculture Research Service, \\ Northern Great Plains Research Laboratory, Mandan, ND 58554-0459
}

\begin{abstract}
Krupinsky, J. M., and Tanaka, D. L. 2001. Leaf spot diseases on winter wheat influenced by nitrogen, tillage, and haying after a grass-alfalfa mixture in the Conservation Reserve Program. Plant Dis. 85:785-789.

When contracts for the Conservation Reserve Program (CRP) expire, highly erodible land that had a long-term vegetative cover composed of grasses or grass-legume mixtures may be converted back to cropland. Considering that some of the same leaf spot pathogens found on grasses can cause diseases on wheat, the management practices used to convert these lands were evaluated for their effect on winter wheat leaf spot diseases. In a 3-year spring wheatwinter wheat-pea crop rotation, the major leaf spot diseases on winter wheat were tan spot and Stagonospora nodorum blotch. Removal of hay or leaving hay in the plots when converting grassland to cropland had no significant effect on leaf spot diseases, indicating that the residue from the grass-alfalfa crop did not influence leaf spot diseases on winter wheat. Tillage treatments did not influence the amount of disease in 1996, but with higher precipitation levels in 1999, higher disease severities were associated with the no tillage treatment. Higher levels of crop residue associated with the no tillage treatment could potentially carry over plant pathogens from one crop to the next. The severity of leaf spot diseases was consistently lower when nitrogen was applied, indicating the importance of nitrogen application when converting grassland to cropland.
\end{abstract}

Additional keywords: no till, Pyrenophora tritici-repentis

The Conservation Reserve Program (CRP) was established by the Food Security Act of 1985 to assist producers with highly erodible land and to conserve and improve soil resources. The voluntary 10year program compensated producers for converting highly erodible or environmentally sensitive land to long-term vegetative cover composed of grasses or grasslegume mixtures. In a multistate project, Karlen et al. (10) reported that several soil quality indicators were improved by placing highly erodible land into perennial grass. After 4 to 7 years in CRP, Staben et al. (20) reported that the soil quality was improved compared with previous management in a wheat (Triticum aestivum L.)-fallow rotation. An increasing concern is how CRP grassland can be managed

Corresponding author: J. M. Krupinsky E-mail: krupinsj@mandan.ars.usda.gov

Mention of a trademark, proprietary product, or company by USDA personnel is intended for explicit description only and does not constitute a guarantee or warranty of the product by the USDA and does not imply its approval to the exclusion of other products that may also be suitable.

Accepted for publication 9 April 2001.

Publication no. D-2001-0521-03R

This article is in the public domain and not copyrightable. It may be freely reprinted with customary crediting of the source. The American Phytopathological Society, 2001. when returned to crop production so that the positive effects of the long-term vegetative cover can be maintained and soil erosion minimized. Reduced tillage has been shown to maintain a greater apparent equilibrium level for soil organic carbon and total nitrogen than does tillage with a plow $(3,4)$. Reduced tillage practices such as minimum tillage and no tillage can be used to maintain soil quality and to minimize soil erosion. Reduced tillage practices increase the risk of leaf spot epidemics compared with conventional tillage because increased levels of crop residue on the soil surface potentially increase primary inoculum of plant pathogens $(1,13,16)$.

The major leaf spot diseases on wheat in the northern Great Plains region usually are tan spot and Stagonospora nodorum blotch, caused by Drechslera triticirepentis (Died.) Shoemaker (teleomorph $=$ Pyrenophora tritici-repentis (Died.) Drechs.) and Stagonospora nodorum (Berk.) Castellani \& E.G. Germano (teleomorph = Phaeosphaeria nodorum (E. Müller) Hedjaroude, respectively. Other common leafspotting pathogens on wheat in this region include: Bipolaris sorokiniana (Sacc.) Shoemaker (teleomorph = Cochliobolus sativus (Ito \& Kuribayashi) Drechs. ex Dastur), cause of spot blotch; Stagonospora avenae Bissett f. sp. triticea T. Johnson (teleomorph = Phaeosphaeria avenaria (G.F. Weber) O. Eriksson f. sp. triticea T. Johnson), cause of Stagonospora avenae blotch; and Septoria tritici Roberge in Desmaz. (teleomorph = Mycosphaerella graminicola (Fuckel) J. Schrot. in Cohn), cause of Septoria leaf blotch. Several of these pathogens form a leaf spot disease complex. The proportion of each pathogen in this complex may vary depending on the environment and location $(7,8,15)$. A number of these leaf-spotting pathogens have been reported on grasses, particularly intermediate wheatgrass $(5,6,11,12,14,19)$. Thus, these pathogens when present on plant residue could carry over to the wheat crop, particularly when plant residue is left on the soil surface. The study objective was to determine if management practices, including residue management, used to convert CRP grassland to cropland affect the severity of leaf spot diseases of winter wheat grown after CRP.

\section{MATERIALS AND METHODS}

Field plots were located on a farm near the Northern Great Plains Research Laboratory, southwest of Mandan, ND, on an Amor loam (fine-loamy, mixed Typic Haploborolls)-Williams loam (fine-loamy, mixed Typic Argiborolls) soil association with a slope of 3 to $15 \%$. The field was in a spring wheat-fallow rotation prior to being converted to CRP grassland in 1987 . The residual soil nitrate-nitrogen prior to the initiation of treatments was $22 \mathrm{~kg} / \mathrm{ha}$ (20 lb/ac) to a depth of $1.5 \mathrm{~m}$. The converted plot area was in CRP for 7 years with a vegetative cover consisting of an intermediate wheatgrass (Thinopyrum intermedium subsp. intermedium (Host) Barkw. \& Dewey)-alfalfa (Medicago sativa L.) mixture. Precipitation was automatically measured with a tipping bucket rain gauge at the site, and data were recorded with a Campbell CR10 datalogger.

The management treatments used for the conversion of the CRP grassland into cropland included a $2 \times 3 \times 2$ factorial of: hayed (aboveground plant biomass removed) and nonhayed plots (all plant biomass left in plots); conventional till, minimum till, and no till; and nitrogen application and no additional nitrogen. The conventional till treatments were disked prior to planting to obtain $<30 \%$ surface residue cover at planting. The minimum till treatments were undercut with a sweep plow at a shallow depth prior to planting to obtain 30 to $60 \%$ surface residue coverage prior to planting. The no till treatments were not tilled and had $>60 \%$ surface residue cover at planting. The no till treat- 
ments received an application of glyphosate contact herbicide within $24 \mathrm{~h}$ of planting. Nitrogen fertilizer was applied in early spring as an application of $\mathrm{NH}_{4} \mathrm{NO}_{3}$ at a rate of $67.2 \mathrm{~kg} \mathrm{~N} / \mathrm{ha}(60 \mathrm{lb}$ nitrogen/ac). The experimental design was a strip-strip-strip plot design with the hay and nitrogen rate treatments stripped and tillage as the subplots within four replications. Each replicate of the study was 30.5 $\times 55 \mathrm{~m}$ in size. Hayed or nonhayed plots $(27 \times 30.5 \mathrm{~m})$ were oriented in an eastwest direction. Tillage plots $(9 \times 30.5 \mathrm{~m})$ were within the hayed treatments in the same east-west direction. Nitrogen or no additional nitrogen treatments $(15 \times 55 \mathrm{~m})$ were oriented in a north-south direction across hayed and tillage treatment plots. The smallest experimental unit with the combination of all variables was $9 \times 15 \mathrm{~m}$.

Aboveground plant biomass was removed for the hayed treatment plots on 11 October 1994. On 14 October, the conventional till and minimum till treatments were undercut with a sweep plow. In the spring, the conventional till was tandem disked twice prior to seeding spring wheat, and the minimum till was undercut with a sweep plow prior to seeding. Initial herbicide spray operations (Fallow Master, 3.9 liters $\mathrm{ha}^{-1}$ ) were done on no till on 14 October 1994. With the annual crop rotation of spring wheat (SW)-winter wheat (WW)-pea, Amidon spring wheat was grown during the first and fourth years. Because of volunteer alfalfa plants in the first spring wheat crop, herbicide (Roundup, 2.3 liters ha ${ }^{-1}$, and Banvel, 1.2 liters $\mathrm{ha}^{-1}$ ) was applied on 13 June 1995, and the spring wheat was reseeded. For the second year, Roughrider winter wheat

Table 1. Analysis of variance for leaf spot severity on Roughrider winter wheat (FL-2) grown under haying, tillage, and nitrogen treatments on 18 June 1996

\begin{tabular}{|c|c|c|}
\hline Source of variation & df & $\begin{array}{l}\text { Mean } \\
\text { squares }^{z}\end{array}$ \\
\hline Replicate (R) & 3 & $0.026 \mathrm{NS}$ \\
\hline Hay & 1 & $0.034 \mathrm{NS}$ \\
\hline Error a, $\mathrm{R} \times$ hay & 3 & 0.006 \\
\hline Nitrogen & 1 & $0.115^{* *}$ \\
\hline Error $\mathrm{b}, \mathrm{R} \times$ nitrogen & 3 & 0.004 \\
\hline Hay $\times$ nitrogen & 1 & $0.006 \mathrm{NS}$ \\
\hline $\begin{array}{l}\text { Error } \mathrm{c}, \mathrm{R} \times \text { hay } \times \\
\text { nitrogen }\end{array}$ & 3 & 0.002 \\
\hline Tillage & 2 & $0.003 \mathrm{NS}$ \\
\hline Error $\mathrm{d}, \mathrm{R} \times$ tillage & 6 & 0.008 \\
\hline Hay $\times$ tillage & 2 & $0.001 \mathrm{NS}$ \\
\hline $\begin{array}{l}\text { Error e, } \mathrm{R} \times \text { hay } \times \\
\text { tillage }\end{array}$ & 6 & 0.004 \\
\hline Nitrogen $\times$ tillage & 2 & $0.004 \mathrm{NS}$ \\
\hline $\begin{array}{l}\text { Error } f, R \times \text { nitrogen } \\
\times \text { tillage }\end{array}$ & 6 & 0.002 \\
\hline $\begin{array}{l}\text { Hay } \times \text { nitrogen } \times \\
\text { tillage }\end{array}$ & 2 & $0.003 \mathrm{NS}$ \\
\hline $\begin{array}{l}\text { Error } \mathrm{g}, \mathrm{R} \times \text { hay } \times \\
\text { nitrogen } \times \text { tillage }\end{array}$ & 6 & 0.003 \\
\hline Total & 47 & \\
\hline
\end{tabular}

(1996 crop) was seeded on 3 October 1995 at 1.3 million viable seeds per acre. For the fifth year, Roughrider winter wheat (1999 crop) was seeded on 30 September 1998 at 1.3 million viable seeds per acre. A Haybuster 8000 furrow drill was used to seed the winter wheat in $25-\mathrm{cm}$ rows. Herbicides (Buctril, 1.2 liters ha ${ }^{-1}$, and 2,4-D ester, 1.2 liters $\mathrm{ha}^{-1}$ ) were applied on 15 May 1996 and 13 May 1999 to all treatments to control broadleaf and grassy weed species within the winter wheat crop. Winter wheat yield $(\mathrm{kg} / \mathrm{ha})$ was measured on a $1 \times 14 \mathrm{~m}$ area for each experimental unit on 8 August 1996 and on a $1.5 \times 14 \mathrm{~m}$ area for each experimental unit on 29 July 1999 with a plot combine. Herbicides were applied after harvest on 8 August 1996 (Landmaster, 3.9 liters $\mathrm{ha}^{-1}$, and Banvel, 1.2 liters ha ${ }^{-1}$ ), 18 October 1996 (Roundup, 1.2 liters ha ${ }^{-1}$ plus $\left.\left[\mathrm{NH}_{4}\right]_{2} \mathrm{SO}_{4}, 19 \mathrm{~kg} \mathrm{ha}^{-1}\right)$, 26 August 1999 (Fallow Master, 2.3 liters $\mathrm{ha}^{-1}$, plus $\left.\left[\mathrm{NH}_{4}\right]_{2} \mathrm{SO}_{4}\right)$, and 7 October 1999 (Roundup plus $\left[\mathrm{NH}_{4}\right]_{2} \mathrm{SO}_{4}$ plus 2,4-D ester, 1.2 liters $\mathrm{ha}^{-1}$ ) on all treatments.

The winter wheat crop was evaluated for leaf spot diseases nine times in 1996 (18 June through 15 July) and 13 times in 1999 ( 8 June through 2 July). The total percentage of necrosis and chlorosis was visually assessed for individual wheat leaves and used as an indicator of the amount of damage caused by leaf spot diseases. Twenty leaves of the same leaf type (e.g., flagleaf) from plants at the same stage of plant development were collected from each of the 48 experimental units at each evaluation. The leaves rated were the flagleaf-2, flagleaf-1, and flagleaf. The growth stages ranged from boot through heading (10 to 10.5, Feekes scale [18]) for the flagleaf-2 ratings, from heading through anthesis (10.5 to 10.5 .4 , Feekes scale [18]) for the flagleaf-1 ratings, and from anthesis through milk/dough (10.5.1 to 11.2, Feekes scale [18]) for the flagleaf ratings.

For evaluation of fungi present, green wheat leaves with lesions, which were collected during the evaluations, were pressed, allowed to dry, and stored in a refrigerator at $3^{\circ} \mathrm{C}$ until they were processed. One to six months after collection, leaf sections about $3 \mathrm{~cm}$ long were surface- sterilized for $3 \mathrm{~min}$ in a $1 \%$ sodium hypochlorite solution containing a surfactant, rinsed in sterile distilled water, plated on water agar in plastic petri dishes, and incubated under a 12-h photoperiod (cool-white fluorescent tubes) at $20^{\circ} \mathrm{C}$. After 7 days, leaf sections were microscopically examined for fungi. Fungi were identified under the microscope by the morphology of the conidia, pycnidia, and pycnidiospores. The number of leaf sections infected with a particular fungus was used as an indicator of the relative importance of that fungus in causing leaf spot diseases in the field. Sixty-four leaves from 1996 and 288 leaves from 1999 were processed.

An analysis of variance was conducted using the arcsine-transformed percentage necrosis data (SAS version 6.12, SAS Institute, Cary, NC) for each disease assessment (Table 1). The analyses were used to obtain a general pattern or statistical trend for treatments and interactions. An analysis of variance was also used to evaluate the yield data. Statistical comparisons within each evaluation were made with Student-Newman-Keul's test (SAS) when the analysis of variance $F$ test was significant at the $P \leq 0.05$ probability level. Statistical differences were evaluated at the probability of $P \leq 0.05$.

\section{RESULTS AND DISCUSSION}

Leaf spot disease complex. Of the 64 winter wheat leaf sections processed from 1996, 95\% were infected with $D$. triticirepentis, $94 \%$ with $S$. nodorum, $23 \%$ with $S$. avenae f. sp. triticea, $13 \%$ with $S$. tritici, and $6 \%$ with $B$. sorokiniana. Of the 288 leaf sections processed from 1999, 100\% were infected with $D$. tritici-repentis, $14 \%$ with $S$. nodorum, $7 \%$ with $S$. avenae f. sp. triticea, $5 \%$ with $S$. tritici, and $0 \%$ with $B$. sorokiniana. Overall, tan spot was the most common disease on winter wheat, followed by Stagonospora nodorum blotch. In general, the 1996 results are consistent with the pattern of fungal isolations from wheat in central North Dakota. For example, in another study, $93 \%$ of 96 spring wheat leaf samples were infected with $S$. nodorum and $81 \%$ with $D$. tritici-repentis in 1996 , and $85 \%$ of 240 spring wheat leaf samples

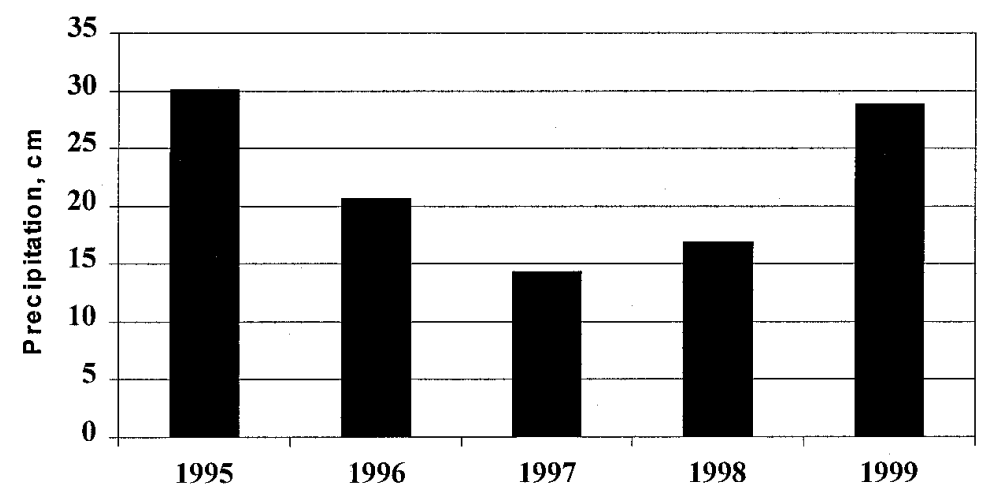

Fig. 1. Total precipitation (cm) in research plots from 15 April to 31 July 1995 to 1999. 
were infected with $S$. nodorum and $65 \%$ with D. tritici-repentis in 1997 (17). Considering that $S$. nodorum is usually a main component of the leaf spot disease complex in this region, the decreased isolation of $S$. nodorum in 1999 compared with 1996 was unexpected. Ordinarily, with increased levels of precipitation as in 1999 (Fig. 1), one would expect an increase in frequency of isolation of $S$. nodorum (8; J. M.
Krupinsky, unpublished data). B. sorokiniana was a minor component in the leaf spot disease complex on winter wheat. Thus, even though the research plots were converted from grassland and were sur-

Table 2. Summary of analyses of variance for leaf spot severity (percent necrosis and chlorosis) on Roughrider winter wheat grown under haying, tillage, and nitrogen treatments in 1996

\begin{tabular}{|c|c|c|c|c|c|c|c|c|c|c|}
\hline \multirow{5}{*}{$\begin{array}{l}\text { Source of } \\
\text { variation }\end{array}$} & \multirow[b]{5}{*}{ df } & \multicolumn{9}{|c|}{ Rating dates } \\
\hline & & June 18 & June 21 & June 24 & June 27 & July 1 & July 9 & July 9 & July 11 & July 15 \\
\hline & & FL-2x & FL-2 & FL-2 & FL-2 & FL-1 & FL-1 & FL & FL & FL \\
\hline & & $17 \%{ }^{y}$ & $25 \%$ & $42 \%$ & $60 \%$ & $39 \%$ & $89 \%$ & $30 \%$ & $45 \%$ & $68 \%$ \\
\hline & & $P>F^{\mathrm{z}}$ & $P>F$ & $P>F$ & $P>F$ & $P>F$ & $P>F$ & $P>F$ & $P>F$ & $P>F$ \\
\hline Replicate & 3 & 0.135 & 0.619 & 0.426 & 0.082 & 0.748 & 0.171 & 0.265 & 0.631 & 0.273 \\
\hline Hay & 1 & 0.102 & 0.791 & 0.279 & 0.410 & 0.732 & 0.229 & 0.306 & 0.494 & $0.011 *$ \\
\hline Nitrogen $(\mathrm{N})$ & 1 & $0.011 *$ & 0.085 & $0.012 *$ & $0.001 * *$ & $0.014 *$ & $0.001 * *$ & $0.001 * *$ & $0.002 * *$ & $0.014 *$ \\
\hline Hay $\times \mathrm{N}$ & 1 & 0.177 & 0.716 & 0.760 & 0.360 & 0.087 & 0.266 & 0.264 & 0.880 & 0.114 \\
\hline Tillage (T) & 2 & 0.674 & 0.898 & 0.331 & 0.794 & 0.358 & 0.217 & 0.225 & 0.796 & 0.691 \\
\hline Hay $\times \mathrm{T}$ & 2 & 0.798 & 0.389 & 0.624 & 0.375 & 0.321 & 0.974 & 0.617 & $0.050 *$ & 0.058 \\
\hline $\mathrm{N} \times \mathrm{T}$ & 2 & 0.162 & 0.117 & 0.071 & 0.319 & 0.401 & 0.145 & 0.354 & 0.290 & 0.089 \\
\hline Hay $\times \mathrm{N} \times \mathrm{T}$ & 2 & 0.467 & 0.620 & 0.106 & 0.096 & 0.794 & 0.369 & 0.580 & $0.020 *$ & 0.684 \\
\hline
\end{tabular}

${ }^{\mathrm{x}} \mathrm{FL}=$ flagleaf or top leaf; FL-1 = first leaf below the flagleaf; FL-2 = second leaf below the flagleaf. The growth stages ranged from boot through heading (10 to 10.5, Feekes scale [18]) for the flagleaf-2 ratings, from heading through anthesis (10.5 to 10.5.4, Feekes scale [18]) for the flagleaf-1 ratings, and from anthesis through milk/dough (10.5.1 to 11.2, Feekes scale [18]) for the flagleaf ratings.

y Overall average disease severity.

$\mathrm{z} *=$ significant at $P \leq 0.05 ; * *=$ significant at $P \leq 0.01$.

Table 3. Summary of analyses of variance for leaf spot severity (percent necrosis and chlorosis) on Roughrider winter wheat grown under haying, tillage, and nitrogen treatments in 1999

\begin{tabular}{|c|c|c|c|c|c|c|c|c|}
\hline \multirow[b]{2}{*}{$\begin{array}{l}\text { Source of } \\
\text { variation }\end{array}$} & \multirow[b]{2}{*}{ df } & \multicolumn{7}{|c|}{ Rating dates } \\
\hline & & $\begin{array}{l}\text { June } 8 \\
\text { FL-2 } \\
45 \%{ }^{\mathrm{y}} \\
P>F^{\mathrm{z}}\end{array}$ & $\begin{array}{l}\text { June } 10 \\
\text { FL-2 } \\
53 \% \\
P>F\end{array}$ & $\begin{array}{l}\text { June } 15 \\
\text { FL-2 } \\
80 \% \\
P>F\end{array}$ & $\begin{array}{l}\text { June } 15 \\
\text { FL-1 } \\
27 \% \\
P>F\end{array}$ & $\begin{array}{l}\text { June } 17 \\
\text { FL-1 } \\
32 \% \\
P>F\end{array}$ & $\begin{array}{l}\text { June } 21 \\
\text { FL-1 } \\
47 \% \\
P>F\end{array}$ & $\begin{array}{l}\text { June } 23 \\
\text { FL-1 } \\
63 \% \\
P>F\end{array}$ \\
\hline Replicate & 3 & $0.045^{*}$ & $0.026^{*}$ & 0.339 & 0.546 & 0.685 & 0.063 & 0.314 \\
\hline Hay & 1 & 0.620 & 0.076 & 0.899 & 0.625 & 0.821 & 0.541 & 0.862 \\
\hline Nitrogen $(\mathrm{N})$ & 1 & $0.006 * *$ & $0.002 * *$ & $0.020 *$ & $0.002 * *$ & $0.001 * *$ & $0.013^{*}$ & $0.004 * *$ \\
\hline Hay $\times N$ & 1 & 0.613 & 0.521 & 0.709 & 0.583 & 0.195 & 0.976 & 0.697 \\
\hline Tillage (T) & 2 & $0.012 *$ & 0.123 & $0.014 *$ & $0.027^{*}$ & $0.007 * *$ & $0.009^{* * *}$ & $0.003 * *$ \\
\hline Hay $\times \mathrm{T}$ & 2 & 0.718 & 0.879 & 0.398 & 0.327 & 0.999 & $0.021 *$ & 0.989 \\
\hline $\mathrm{N} \times \mathrm{T}$ & 2 & 0.078 & 0.764 & 0.301 & 0.064 & 0.329 & 0.974 & 0.205 \\
\hline Hay $\times \mathrm{N} \times \mathrm{T}$ & 2 & 0.768 & 0.799 & 0.854 & 0.488 & 0.932 & 0.099 & 0.350 \\
\hline
\end{tabular}

${ }^{\mathrm{x}} \mathrm{FL}=$ flagleaf or top leaf; FL-1 = first leaf below the flagleaf; FL-2 = second leaf below the flagleaf. The growth stages ranged from boot through heading (10 to 10.5, Feekes scale [18]) for the flagleaf-2 ratings, from heading through anthesis (10.5 to 10.5.4, Feekes scale [18]) for the flagleaf-1 ratings, and from anthesis through milk/dough (10.5.1 to 11.2, Feekes scale [18]) for the flagleaf ratings.

${ }^{\mathrm{y}}$ Overall average disease severity.

$\mathrm{z} *$ significant at $P \leq 0.05 ; * *=$ significant at $P \leq 0.01$

Table 4. Summary of analyses of variance for leaf spot severity (percent necrosis and chlorosis) on Roughrider winter wheat grown under haying, tillage, and nitrogen treatments in 1999

\begin{tabular}{|c|c|c|c|c|c|c|c|}
\hline \multirow[b]{2}{*}{$\begin{array}{l}\text { Source of } \\
\text { variation }\end{array}$} & \multirow[b]{2}{*}{ df } & \multicolumn{6}{|c|}{ Rating dates } \\
\hline & & $\begin{array}{l}\text { June 25 } \\
\text { FL-1x } \\
69 \% \%^{y} \\
P>F^{z}\end{array}$ & $\begin{array}{l}\text { June 28 } \\
\text { FL-1 } \\
83 \% \\
P>F\end{array}$ & $\begin{array}{l}\text { June } 23 \\
\text { FL } \\
19 \% \\
P>F\end{array}$ & $\begin{array}{l}\text { June } 28 \\
\text { FL } \\
31 \% \\
P>F\end{array}$ & $\begin{array}{l}\text { June } 30 \\
\text { FL } \\
41 \% \\
P>F\end{array}$ & $\begin{array}{l}\text { July } 2 \\
\text { FL } \\
55 \% \\
P>F\end{array}$ \\
\hline Replicate & 3 & 0.172 & 0.165 & 0.235 & 0.091 & 0.136 & 0.085 \\
\hline Hay & 1 & 0.253 & 0.194 & 0.388 & 0.290 & 0.911 & 0.695 \\
\hline Nitrogen $(\mathrm{N})$ & 1 & 0.107 & $0.012 *$ & 0.056 & $0.023^{*}$ & 0.151 & 0.163 \\
\hline Hay $\times N$ & 1 & 0.481 & 0.604 & 0.549 & 0.175 & 0.586 & 0.310 \\
\hline Tillage (T) & 2 & 0.166 & $0.025^{*}$ & 0.052 & 0.165 & $0.008 * *$ & 0.963 \\
\hline Hay $\times T$ & 2 & 0.497 & 0.131 & 0.504 & 0.107 & 0.254 & 0.138 \\
\hline $\mathrm{N} \times \mathrm{T}$ & 2 & 0.896 & 0.495 & 0.858 & 0.424 & 0.294 & 0.898 \\
\hline Hay $\times \mathrm{N} \times \mathrm{T}$ & 2 & 0.642 & 0.741 & 0.987 & 0.445 & 0.130 & 0.468 \\
\hline
\end{tabular}

${ }^{\mathrm{x}} \mathrm{FL}=$ flagleaf or top leaf; FL-1 = first leaf below the flagleaf; FL-2 = second leaf below the flagleaf. The growth stages ranged from boot through heading (10 to 10.5 , Feekes scale [18]) for the flagleaf-2 ratings, from heading through anthesis (10.5 to 10.5.4, Feekes scale [18]) for the flagleaf-1 ratings, and from anthesis through milk/dough (10.5.1 to 11.2, Feekes scale [18]) for the flagleaf ratings.

y Overall average disease severity.

$\mathrm{z} *=$ significant at $P \leq 0.05 ; * *=$ significant at $P \leq 0.01$. 


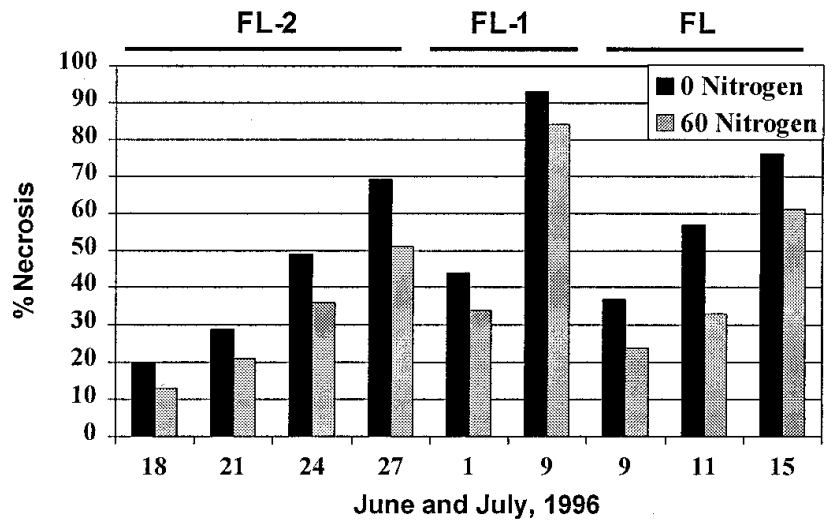

Fig. 2. Percent leaf necrosis caused by the leaf spot disease complex on Roughrider winter wheat related to nitrogen (no additional nitrogen versus additional nitrogen) averaged over tillage and hay in 1996. FL = flagleaf, FL-1 = first leaf below FL, FL-2 = second leaf below FL. The growth stages ranged from boot through heading (10 to 10.5, Feekes scale [18]) for the flagleaf-2 ratings, from heading through anthesis (10.5 to 10.5.4, Feekes scale [18]) for the flagleaf-1 ratings, and from anthesis through milk/dough (10.5.1 to 11.2, Feekes scale [18]) for the flagleaf ratings.

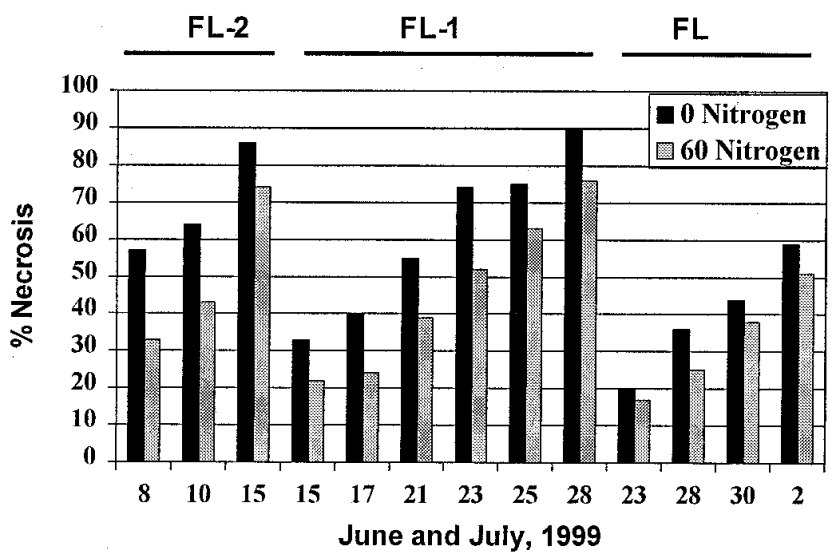

Fig. 3. Percent leaf necrosis caused by the leaf spot disease complex on Roughrider winter wheat related to nitrogen (no additional nitrogen versus additional nitrogen) averaged over tillage and hay in 1999. FL = flagleaf, FL-1 = first leaf below FL, FL-2 = second leaf below FL. The growth stages ranged from boot through heading (10 to 10.5, Feekes scale [18]) for the flagleaf-2 ratings, from heading through anthesis (10.5 to 10.5.4, Feekes scale [18]) for the flagleaf-1 ratings, and from anthesis through milk/dough (10.5.1 to 11.2, Feekes scale [18]) for the flagleaf ratings.

Table 5. Analysis of variance for yield $(\mathrm{kg} / \mathrm{ha})$ of Roughrider winter wheat grown under haying, tillage, and nitrogen treatments in 1996 and 1999

\begin{tabular}{lccc}
\hline Source of variation & df & $\begin{array}{c}\mathbf{1 9 9 6} \\
\text { Mean squares }\end{array}$ & $\begin{array}{c}\mathbf{1 9 9 9} \\
\text { Mean squares }\end{array}$ \\
\hline Replicate $(\mathrm{R})$ & 3 & $462,669 \mathrm{NS}$ & $141,773 \mathrm{NS}$ \\
Hay & 1 & $940,240^{*}$ & $40,833 \mathrm{NS}$ \\
Error a, $\mathrm{R} \times$ hay & 3 & 57,303 & 30,556 \\
Nitrogen & 1 & $662,230 \mathrm{NS}$ & $9,835,541^{* *}$ \\
Error b, $\mathrm{R} \times$ nitrogen & 3 & 409,323 & 96,554 \\
Hay $\times$ nitrogen & 1 & $14,981 \mathrm{NS}$ & $3 \mathrm{NS}$ \\
Error c, $\mathrm{R} \times$ hay $\times$ nitrogen & 3 & 46,731 & 33,246 \\
Tillage & 2 & $276,296 \mathrm{NS}$ & $404,765^{*}$ \\
Error d, R $\times$ tillage & 6 & 114,231 & 62,429 \\
Hay $\times$ tillage & 2 & $213,628 \mathrm{NS}$ & $59,905 \mathrm{NS}$ \\
Error $\mathrm{e}, \mathrm{R} \times$ hay $\times$ tillage & 6 & 45,197 & 51,351 \\
Nitrogen $\times$ tillage & 2 & $97,384 \mathrm{NS}$ & $52,001 \mathrm{NS}$ \\
Error f, R $\times$ nitrogen $\times$ tillage & 6 & 39,558 & 24,360 \\
Hay $\times$ nitrogen $\times$ tillage & 2 & $96,437 \mathrm{NS}$ & $61,721 \mathrm{NS}$ \\
Error $\mathrm{g}, \mathrm{R} \times$ hay $\times$ nitrogen $\times$ tillage & 6 & 110,444 & 16,490 \\
Total & 47 & & \\
\hline
\end{tabular}

$\mathrm{z} * *=$ significant at $P \leq 0.01 ; *$ significant at $P \leq 0.05 ; \mathrm{NS}=$ not significant at $P \leq 0.05$. rounded by a CRP grassland (intermediate wheatgrass-alfalfa mixture) there was not a major presence of spot blotch on winter wheat.

Leaf spot diseases and management practices. The severity of leaf spot diseases on Roughrider winter wheat was not influenced by haying, removal of plant biomass, when the grassland was converted to cropland (Tables 2 to 4). Although there were three significant interactions (hay $x$ nitrogen, hay $\times$ tillage, and hay $\times$ nitrogen $x$ tillage) out of 22 analyses, there was no consistent pattern (Tables 2 to 4). Apparently, the removal of grass residues and the possible inoculum of plant pathogens carried over on the residue did not influence the severity of diseases present in the plots. Thus, an increase in leaf spot diseases would not be a cause for concern to producers leaving the accumulated vegetation and organic residues on the surface to prevent soil erosion on these highly erodible lands.

The application of nitrogen decreased the severity of leaf spot diseases (an average of $13 \%$ ) for a range of disease severities on the top three leaves of winter wheat in 1996 (Fig. 2). Disease severity was significantly lower on winter wheat plants that had additional nitrogen compared with those without a nitrogen application in eight out of nine evaluations (Table 2). A consistent pattern was again detected in 1999 with lower disease severities (an average of 14\% less) on plants receiving a nitrogen application (Fig. 3). Disease severity was significantly lower on plants with additional nitrogen in nine out of 13 evaluations (Tables 3 and 4). This increase in leaf spot severity with nitrogen deficiency is consistent with other reports. In the same region, Krupinsky et al. reported that when significant differences were evident for nitrogen treatments, higher disease severity was associated with low nitrogen treatments (15). In Saskatchewan, Fernandez et al. observed an increase in leaf spot severity on spring wheat with an increase in nitrogen deficiency (7). In Indiana, Huber et al. reported that the severity of tan spot on soft red winter wheat cultivars decreased as the rate of nitrogen increased (9). Although yields for the nitrogen treatment were not significantly different in 1996 (Table 5), a lower yield $(2,103 \mathrm{~kg} / \mathrm{ha}[31 \mathrm{bu} / \mathrm{ac}])$ was associated with the no additional nitrogen treatment compared with the additional nitrogen treatment $(2,338 \mathrm{~kg} / \mathrm{ha}$ [35 bu/ac]). In 1999, yield differences for the nitrogen treatments were significant (Table 5), with a yield of 1,464 kg/ha (22 bu/ac) for the no additional nitrogen treatment compared with $2,369 \mathrm{~kg} / \mathrm{ha}(35 \mathrm{bu} / \mathrm{ac})$ for the additional nitrogen treatment. With higher precipitation levels during the growing season in 1999 (29 cm compared with $21 \mathrm{~cm}$ from 1 April to 31 July; Fig. 1), environmental conditions were more favorable for disease 
development in 1999. During May, when the crop was elongating, the difference in precipitation was even more dramatic, 15 cm in 1999 compared with $6 \mathrm{~cm}$ in 1996. These results point out the importance of adequate or supplemental nitrogen when converting CRP grassland to cropland, especially with higher precipitation levels. Neither the presence of alfalfa in the CRP grassland nor the presence of the legume pea in the crop rotation appeared to provide adequate residual nitrogen for the winter wheat crop.

There were no significant differences among the tillage treatments for leaf spot diseases in 1996 (Table 2). In contrast, a pattern of higher disease severity with the no till treatment compared with the conventional till and minimum till treatments was found in 1999 (Fig. 4). Differences in disease severity were significant in eight of the 13 evaluations (Tables 3 and 4). Thus, higher disease severities were associated with the higher residue level when environmental conditions are more favorable for disease development. Although there were no significant yield differences with the tillage treatments in 1996 (Table 5), a yield of $2,071 \mathrm{~kg} / \mathrm{ha}(31 \mathrm{bu} / \mathrm{ac})$ was associated with the no till treatment compared with $2,318 \mathrm{~kg} / \mathrm{ha}(34 \mathrm{bu} / \mathrm{ac})$ for the minimum till treatment and $2,272 \mathrm{~kg} / \mathrm{ha}(34$ $\mathrm{bu} / \mathrm{ac})$ for the conventional till treatment. With significant yield differences in 1999 (Table 5), a yield of $1,752 \mathrm{~kg} / \mathrm{ha}$ (26 bu/ac) for the no till treatment was similar to the minimum till treatment $(1,927 \mathrm{~kg} / \mathrm{ha}[29$ $\mathrm{bu} / \mathrm{ac}])$ but less than the conventional till treatment $(2,069 \mathrm{~kg} / \mathrm{ha}$ [31 bu/ac]). Yields for the minimum till and conventional till treatments were similar. Reduced tillage often results in increased foliar disease severity, but these differences are not always economically important in the more arid regions of the northern Great Plains, because the environmental conditions, such as rainfall events, favorable for pathogen dissemination and infection occur more sporadically compared with higher rainfall areas $(1,2)$; but with the higher precipitation levels in 1999, more disease and lower yield were associated with the no till treatment.

Multiple evaluations for disease severity on winter wheat over 2 years evaluated the impact of management practices, including residue management, on disease development on winter wheat. Overall, the initial effect of haying of CRP grassland had no significant influence on leaf spot diseases on winter wheat. Tillage treatments did not influence the amount of disease in 1996; but with higher precipitation in 1999, higher levels of disease and lower yield were associated with the no till treatment in comparison with the conventional till treatment. The severity of leaf spot diseases was consistently lower when nitrogen was applied. This indicates the importance of nitrogen application when converting CRP grassland.

\section{ACKNOWLEDGMENTS}

We thank our cooperators: NRCS, Consolidated Farm Service Agency, and Keith Boehm and Lyle Boehm for the use of their land; D. Wetch, J. Gross, C. Flakker, and J. Hartel for technical assistance; D. Schlenker for weather data; G. Richardson for statistical advice; and Michael Lindstrom and Don Mathre for their reviews and constructive comments.

\section{LITERATURE CITED}

1. Bailey, K. L., and Duczek, L. J. 1996. Managing cereal diseases under reduced tillage. Can. J. Plant Pathol. 18:159-167

2. Bailey, K. L., Johnston, A. M., Kutcher, H. R., Gossen, B. D., and Morrall, R. A. A. 2000. Managing crop losses from foliar diseases with fungicides, rotation, and tillage in the Saskatchewan Parkland. Can. J. Plant Sci. 80:169-175.

3. Bauer, A., and Black, A. L. 1981. Soil carbon, nitrogen, and bulk density comparisons in two cropland tillage systems after 25 years in virgin grassland. Soil Sci. Soc. Am. J. 45:1166-1170.

4. Black, A. L., and Tanaka, D. L. 1997. A conservation tillage-cropping systems study in the northern Great Plains of the United

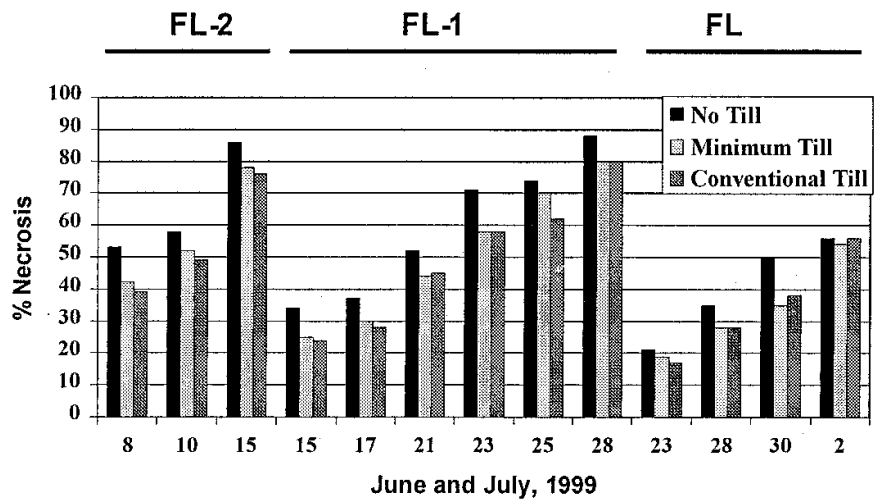

Fig. 4. Percent leaf necrosis caused by the leaf spot disease complex on Roughrider winter wheat related to tillage (conventional till $=<30 \%$ cover, minimum till $=30$ to $60 \%$ cover, no till $=>60 \%$ cover) averaged over nitrogen and hay treatments; FL = flagleaf, FL-1 = first leaf below FL, FL-2 = second leaf below FL. The growth stages ranged from boot through heading (10 to 10.5, Feekes scale [18]) for the flagleaf-2 ratings, from heading through anthesis (10.5 to 10.5.4, Feekes scale [18]) for the flagleaf-1 ratings, and from anthesis through milk/dough (10.5.1 to 11.2, Feekes scale [18]) for the flagleaf ratings.
States. Chapter 24, pages 335-342 in: Soil Organic Matter in Temperate Agroecosystems, Long-Term Experiments in North America. E. A. Paul, K. Paustian, E. T. Elliott, and C. V. Cole, eds. CRC Press, Boca Raton, FL.

5. Duczek, L. J., Jones-Flory, L. L., Reed, S. L., Bailey, K. L., and Lafond, G. P. 1996. Sporulation of Biopolaris sorokiniana on the crowns of crop plants grown in Saskatchewan. Can. J. Plant Sci. 76:861-867.

6. Farr, D. F., Bills, G. F., Chamuris, G. P., and Rossman, A. Y. 1989. Fungi on Plants and Plant Products in the United States. American Phytopathological Society, St. Paul, MN.

7. Fernandez, M. R., Zentner, R. P., McConkey, B. G., and Campbell, C. A. 1998. Effects of crop rotations and fertilizer management on leaf spotting diseases of spring wheat in southwestern Saskatchewan. Can. J. Plant Sci. 78:489-496.

8. Gilbert, J., Woods, S. M., and Tekauz, A. 1998. Relationship between environmental variables and the prevalence and isolation frequency of leaf-spotting pathogens in spring wheat. Can. J. Plant Pathol. 20:158-164.

9. Huber, D. M., Lee, T. S., Ross, M. A., and Abney, T. S. 1987. Amelioration of tan spotinfected wheat with nitrogen. Plant Dis. 71:49-50.

10. Karlen, D. L., Rosek, M. J., Gardner, J. C., Allan, D. L., Alms, M. J., Bezdicek, D. F., Flock, M., Huggins, D. R., Miller, B. S., and Staben, M. L. 1999. Conservation Reserve Program effects on soil quality indicators. J. Soil Water Conserv. 54:439-444.

11. Krupinsky, J. M. 1992. Grass hosts of Pyrenophora tritici-repentis. Plant Dis. 76:92-95.

12. Krupinsky, J. M. 1997. Aggressiveness of Stagonospora nodorum isolates from perennial grasses on wheat. Plant Dis. 81:10321036.

13. Krupinsky, J. M. 1999. Influence of cultural practices on Septoria/Stagonospora diseases. Pages 105-110 in: Septoria and Stagonospora Diseases of Cereals: A Compilation of Global Research. M. Van Ginkel, A. McNab, and J. M. Krupinsky, ed. CIMMYT, Mexico, D.F., Mexico.

14. Krupinsky, J. M., and Berdahl, J. D. 1984. Evaluation of Agropyron intermedium for reactions to various leaf spot diseases. Plant Dis. 68:1089-1091.

15. Krupinsky, J. M., Halvorson, A. D., and Black, A. L. 1998. Leaf spot diseases of wheat in a conservation tillage study. Pages 322-326 in: Helminthosporium Blights of Wheat: Spot Blotch and Tan Spot. E. Duveiller, H. J. Dubin, J. Reeves, and A. McNab, ed. CIMMYT, Mexico, D. F., Mexico.

16. Krupinsky, J. M., McMullen, M., Bailey, K. L., Duczek, L. J., and Gossen, B. D. 1997. Advancing the Art - Diseases. Pages 29-33 in: Advancing the Art. Manitoba-North Dakota Zero Tillage Farmer's Association, Brandon, Manitoba.

17. Krupinsky, J. M., and Tanaka, D. 2000. Leaf spot diseases on spring wheat cultivars influenced by the application of potassium chloride. Pages 171-176 in: Proc. Great Plains Soil Fertility Conference, Vol. 8, March 7-8, 2000. A. J. Schlegel, ed. Denver, CO.

18. Large, E. C. 1954. Growth stages in cereals. Plant Pathol. 3:128-129.

19. Sprague, R. 1950. Diseases of cereals and grasses in North America. Ronald Press, New York.

20. Staben, M. L., Bezdicek, D. F., Smith, J. L., and Fauci, M. F. 1997. Assessment of soil quality in Conservation Reserve Program and wheat fallow soils. Soil. Sci. Soc. Am. J. 61:124-130. 